\title{
Study the Effect of Palm Date Extract against Bacterial and Fungal Species Isolated from Ear Infection
}

\author{
Amidah Ali Atiyah $^{\mathrm{a}}$ Rasha Abdui Atheem Yaseen ${ }^{\mathrm{b}}$ Afrah Abdullah Jasim \\ ${ }^{a}$ Department of Biology, College of Applied Science, Samarra University, Samarra, Iraq \\ ${ }^{b}$ Department of Biology, College of Education, Samarra University .Samarra .Iraq. \\ ${ }^{c}$ Department of Biology, college of education, Samarra University ,Samarra, Iraq.
}

ami.iq14@gmail.com rasha.fungi@gmail.com afrah.abdullah89@gmail.com

Submission date:- 15/10/2017 Acceptance date:- 6/12/2018 Publication date:- 8/10/2018

Keywords: Aspergillus flavus, Aspergillus, Pencillium spp, Cladosporium.

\begin{abstract}
A number of bacterial and fungal strains associated with external ear infections from the Samarra General Hospital were isolated and included bacterial species (Escherichia coli, Streptococcus pneumonia, Klebsiella spp, Staphylococcus aureus, Pseudomonas aeruginosa) and fungal species. (Aspergillus flavus, Aspergillus niger, Pencillium spp, Cladosporium) The genus Phoenix doctitera is an important and rich variety of nutrients. It has been tested as a subject for study. Its biological effect on pollen was tested against bacterial and fungal species using ethanol and distilled distilled water. The results showed an inhibitory effect against some of the abovementioned species with the highest inhibitory against Staphyiococcus .aureus $0.25 \pm 2.23 \mathrm{~mm}$ and the highest inhibition of Cladosporium $0.2 \pm 2.0 \mathrm{~mm}$. Bacteria resistance E.coli, Klebsiella and A. fungus A. flavus, A. niger for the extract of alcohol as the water extract did not have any effect against bacterial and fungal species.
\end{abstract}

\section{1- Introduction}

The ear is a member of hearing and balance in human and consists of three functional parts, the external ear that transmits the sound waves to the drum and the middle ear which moves the vibrations of the drum to the inner which in turn forms the inner part of the ear and tranforms the vibrations into nerve impulses that the brain translates, ear infection is very commen in children it affects any of the three part of the outer ear, middle and the inner, the indicators and symptoms vary accordind to the location of the injury [1],[2].

The area of the ear, nose and pharynx is exposed to bacterial and fungal contamination through bacterial laden dust and fungal spores for direct contact with air and the external environment which are often polluted as environment suitable for the growth of bacteria and fungi in addition to that most bacteria and fugi opportunistic it can cause many diseases, especially infections of the middle ear [3].

Ear infection are a medically important cause of pain and nerve irritation when the inflammation is in the outside ear or many lead to hearing loss in the cause of the middle ear infection, It also effects the pronunciation process and the level of intelligence [4], inflammation of the nose and pharynx which form the beginning of the upper respiratory tract many lead to the transmission of the pathogen and then inflammation to the rest of the respiratory organs [5].

Medical plant continue to provide valuable therapeutic factors whether in modern medicine or traditional medicine [6] the sex of phoenix is one of the most widely cultivated major groups around the world because it is an important food source for humans because it contain carbohydrates, proteins and amino acids, Palm farm are a source of support for farmers especially in Iraq different parts of it are used in traditional medicine to treat various disorders memory, fever, paralysis, loss of consciousness and neurological disordersn[7].

Palm date contain a group of fatty acids such as Oliec in the rate of $(50.10 \%)$ and the Linolic in the rate of $(19.23 \%)$ and the Palmitic in the rate of $(9.83 \%)$ and the Stearic in the rate of $(7.51 \%)$ [8]. the result of the 
chemical analysis showed that the pollination of Palm date contains citroids, citrolates, and flavonoids which have been shown to be powerful antioxidants[9]. As Al samarai,2016 explained during the chemical examination of the components that the grains contain citrules, flavonoids, alkaloids, protein , carbohydrate, cliques, phenolic compounds , tannins , turbines, sapphons, coumarin[10], Kothar,2011 also confirmed that the a cetone and methanolic extract of the palm date had an inhibitory effect against species of bacteria included (Bacillus subtillis, E.coli, Ps.aeruginosa, Shigella flexeneri, Staphylococcus aureus , Streptococcus pyogenes ) [11] ..Astudy in iran has shown that Palm date has an inhibitory effect against several bacterial strains of Gram positive bacteria [12] , Shraideh also demonstrated that the Palm date effect on the growth of Candida albicans.

\section{2- The importance of Palm date the study aims.}

1-Isolation and diagnosis of bacterial and fungal species from several samples with ear infection from Samarra general hospital .

2-Statement of the effect of alcohol and water extracts in inhibiting isolated microbial and fungal species.

\section{3-Materials \& Methods}

\subsection{Collection of Specimens:}

40 samples were collected , 20 of which were bacterial and 20 were fungal and different ages and both sexes of people with ear infection and cotton swabs and in cooperation with a group of specialists of the nose, ear and throat in Samarra general hospital during the period from October month to December month of the year 2016 , other samples of unsatisfactory cases were collected as control models.

Bacterial Isolates: samples were planted on the following media .

1- Blood agar

2 - MacConkey's agar

3-Nutrient agar

4-MannitolSalt Agar to diagnose bacteria S.aureus.

All medias attended and dissolved in distilled water and then sterilized by autoclave at a temperature $121 \mathrm{C}^{0}$ and pressure 15 pound for 15 mintes, the dishes were incubated aerobically and at a temperature $37 \mathrm{C}^{0}$ for 24 hour.

\subsection{Diagnosis of bacterial isolates}

The morphological and chemical properties of developing colonies were observed.

A-microscopy and agricultural characteristics: The bacteria were first identified by observation agricultural characteristics of the developing colonies on the media used form where size, height and colonial color and attended thin swabs and a pigment with a Gram stain to observe cell shapes, arrange and their susceptibility to pigmentation [13].

\section{B-Bacteriological test}

IMVIC test were conducted includes ( Indol test , Methyl red , Vog's proskauer , Cimmon citrate ) [14],[13] As well as tests Oxidase, Catalase,Coagulase to confirm isolated bacterial species [15].

\section{4- Fungal isolates :}

Samples are planted on the media potato dextrose agar (PDA) and incubated dishes at a temperature $25 \mathrm{C}^{0}$ for a week with growth note every two days and the result is negative if growth dose not appear swabs from all models were made on aglass slide using a blue acetone phenol stain for the purpose of microscopy.

\section{5- Preparation of the plant extract for Palm date}

Ahmed method adopted (2010) [16] in the preparation of water and alcohol extracts added $40 \mathrm{~m}$ from Palm pollen powder both on my own to $160 \mathrm{ml}$ from distilled water and in the case of alcohol extract the same quantity has been added to ethyl alcohol at a concentration $95 \%$ then leave the mix for 24 hour in the refrigerator for the purpose of soaking and then filtered through several layers of sterile gauzo then the resulting extracts were concentrated by rotary evaporator and at a temperature $40 \mathrm{C}^{0}$ until a heavy liquid is obtained and the solution is 
filtered with microbial filtration membranes(Micropipette) minute openings and diameter $0.22 \mu \mathrm{L}$ each sample is placed in sealed glass bottles and marked and stored in the refrigerator unitil use .

\section{6- Test the Sensitivity of Bacteria and Fungi Isolated to Plant Extract}

Effectiveness of the plant extract was tested by diffusion method in dish ( Agar Well diffusion), It both PDA media and nutrient agar are prepared according to manufacturer's instructions in the case of bacterial samples, a swab was taken from the newly grown farm and place a tube of the container on $5 \mathrm{ml}$ of feeding medium ( Nutrient broth ) mix with the mixer the tubes were incubated for half an hour after the media was sterilized by autoclave and at a temperature $60 \mathrm{C}^{0}$ then add the bacterial suspension to the medium and mix gently and then varnishes in dishes petri after the hardening of the dishes , a $5 \mathrm{ml}$ hole drill was performed with a sterile fline hole and add the alcohol and water extract in the hole for each extract and use 3 replicates using the micropipette at the same time control dishes were made by placing 75 microliter distilled sterile water as a negative control sample and incubating the dishes at a temperature $37 \mathrm{C}^{0}$ for 18-24 hour the diameter of the inhibition area was then measured, in the case of fungal samples, it is similar to bacterial specimens with different plant medium and incubation time 24-48 hour, positive control dishes were also made using antigungal nystatin as a positive control sample [17].

\section{7- Results \&Discussion}

The results of isolation and identification showed there are anumber of the bacterial and fungal species that accompanied the otitis, the most important ones are following :(Pseudomonas aeroginosa, Escherichia coli , Streptococcus pneumonia, Klebsiella spp, Staphylococcus areus). The higher ratio of appearance are S.aureus whereas the number of the fungal species are (3) which belonged to (4) genera:Aspergillus flavus, Aspergillus niger, Pencillium spp) and Cladosporium). The higher ratio of appearance in A.niger. This is agreed with Abd Alshahid [18] (when he enabled to isolate [14] isolation for A.niger and [14] isolations for A.fungiotus and [8] isolations for A.flavus and [3] isolations for A.terrus.

\section{8-Test of the sensitivity of the plant extract from the palm pollen against the bacterial isolation}

The obvious results in the table (1) and the figures (A-E) indicated there are asignificant effect of the alcoholic extract of palm pollen on inhibiting the isolated bacterial spp. The higher inhibitory ratio at Streptococcus is $0.25+_{-} 2.23 \mathrm{ml}$ compared to the control group that attained $0.00+_{-} 0.00$ and Streptococcus pneumonia attained $0.15+2.03 \mathrm{ml}$ and then Pseudomonas aeroginosa, attained $0.26+1.8 \mathrm{ml}$ wherease the ratio of inhibition is zero at Escherichia coli and Klebsiella spp. The aqueous extract didn't show anyinhibitory impact on the isolated species.

Table (1) Effect of Palm pollen extract on the isolated bacterial species.

\begin{tabular}{|c|c|c|c|}
\hline $\begin{array}{c}\text { Type of treatment } \\
\text { Bacterial.spp }\end{array}$ & Alkoholic Extract & Aqueou Extract & Control \\
\hline E.coli & $\mathbf{E 0 . 0 0 \pm 0 . 0 0}$ & $\mathbf{A ~ 0 . 0 0} \pm \mathbf{0 . 0 0}$ & $\mathbf{B 0 . 0 0} \pm 00.00$ \\
\hline Klebsella.spp & $\mathbf{E 0 . 0 0 \pm 0 . 0 0}$ & $\mathbf{A ~ 0 . 0 0} \pm \mathbf{0 . 0 0}$ & $\mathbf{B 0 . 0 0} \pm \mathbf{0 . 0 0}$ \\
\hline S.aureus & $\mathbf{A 0 . 2 5} \pm \mathbf{2 . 2 3}$ & $\mathbf{A ~ 0 . 0 0} \pm \mathbf{0 . 0 0}$ & $\mathbf{B ~ 0 . 0 0} \pm \mathbf{0 . 0 0}$ \\
\hline Streptococcus pneumoniae & $\mathbf{B 0 . 1 5} \pm \mathbf{2 . 0 3}$ & $\mathbf{A ~ 0 . 0 0} \pm \mathbf{0 . 0 0}$ & $\mathbf{B ~ 0 . 0 0} \pm \mathbf{0 . 0 0}$ \\
\hline Ps.aeruginosa & $\mathbf{C ~ 0 . 2 6} \pm \mathbf{1 . 8}$ & $\mathbf{A ~ 0 . 0 0} \pm \mathbf{0 . 0 0}$ & $\mathbf{B ~ 0 . 0 0} \pm \mathbf{0 . 0 0}$ \\
\hline
\end{tabular}

*The similar letters indicate there are no significant differences $(0.05 \leq \mathrm{P})$ among they groups vertical comparison).

*The different letters indicate there are significant differences $(\mathrm{P} \geq 0.05)$ among groups vertical comparison. 

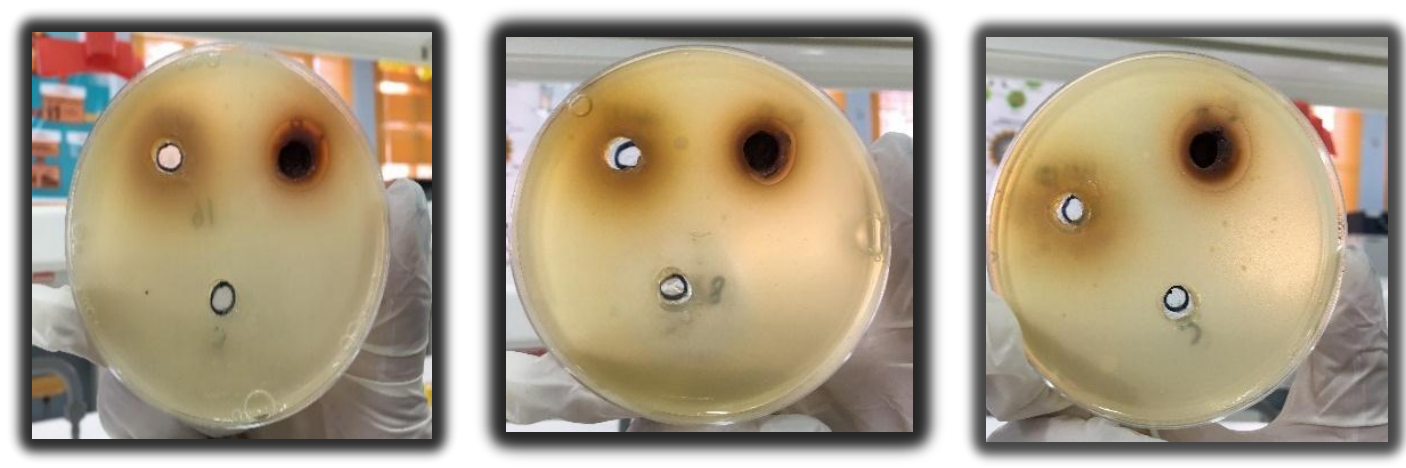

Figure(C)illustratedSt.pneumonia

Figur(B)illustratedPs.aerug

Figur(A) illustratedS.aureus

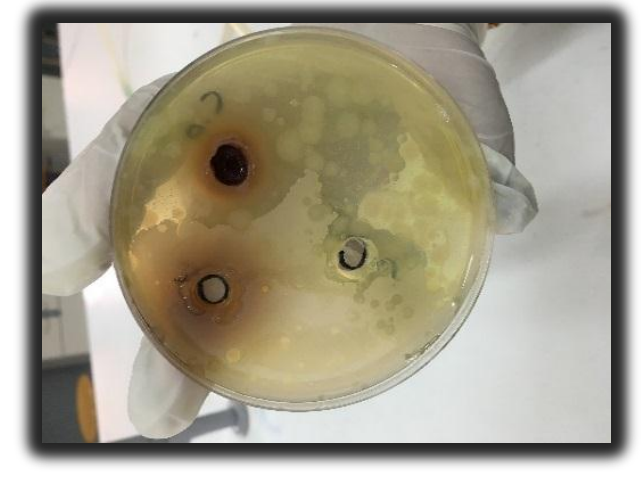

Figure (E) illustrated Klebsiella

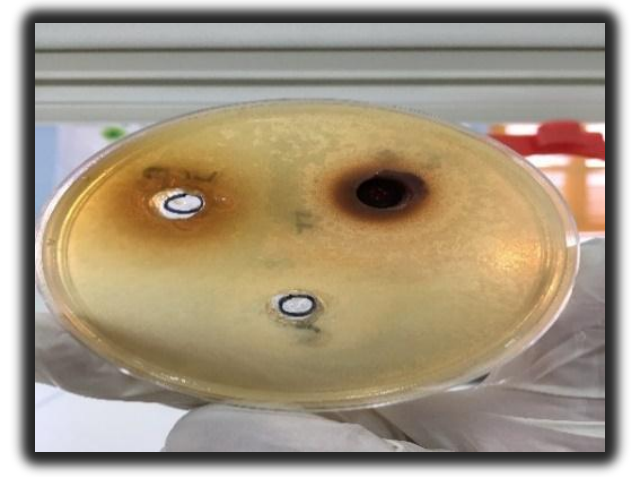

Figure(D) illustrated E.coli

fig (1) Effect of the Palm pollen extract on the isolated bacterial species.

A:S. aureus

B:Ps.aeruginosa

C:St.pneumonia

D: Esherichia coli

E: Klebsiella

\section{9-Testing the sensitivity of the palm pollen extract against the fungal isolations}

The illustrated results in the table(2) and figures (A-D) showed there was asignificant impact of the alcoholic extract on inhibiting Cladosporium and Pencillium spp. That attained $0.1 \pm 1.6$ and $0.2 \pm 2.0 \mathrm{ml}$ respectively, compared to the control that attained $1.5 \mathrm{ml}$ whereas there were no effect on A.niger and A.flavus. The aqueous extract didn't show any effect on the fungi. 
Table(2) Effect of Palm pollen extract impact on fungal isolations.

\begin{tabular}{|l|l|l|l|}
\hline \multicolumn{1}{|c|}{ Kind of treatment } & Alcoholic extract & Aqueous extract & Control \\
genera & & & \\
\hline A.flvus & & & \\
\hline A.niger & $\mathbf{0 . 0} \pm \mathbf{0 . 0} \mathrm{C}$ & $\mathbf{0 . 0} \pm \mathbf{0 . 0} \mathrm{A}$ & $\mathbf{1 . 5} \pm \mathbf{A 0 . 0}$ \\
\hline Pencillium.spp & $\mathbf{0 . 0} \pm \mathbf{0 . 0} \mathrm{C}$ & $\mathbf{0 . 0} \pm \mathbf{A ~ 0 . 0}$ & $\mathbf{1 . 5} \pm \mathbf{A 0 . 0}$ \\
\hline Cladosporium & $\mathbf{1 . 6} \pm \mathbf{0 . 1} \mathrm{B}$ & $\mathbf{0 . 0} \pm \mathbf{0 . 0} \mathrm{A}$ & $\mathbf{1 . 5} \pm \mathbf{A 0 . 0}$ \\
\hline
\end{tabular}

The similar letters indicate there are no significant differences $(0.0<\mathrm{p})$ among the groups (vertical comparison). The different letters indicate there are significant differences ( $\mathrm{p} \geq 0.05)$ among the group(vertical comparison).

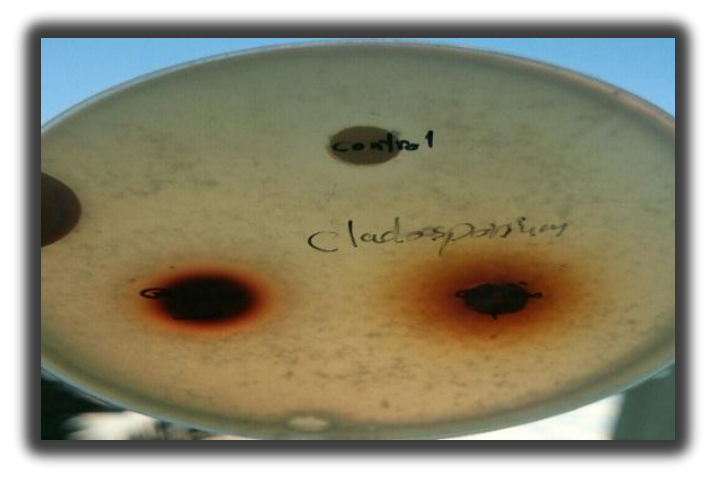

Figure (A) illustrated Cladosporium

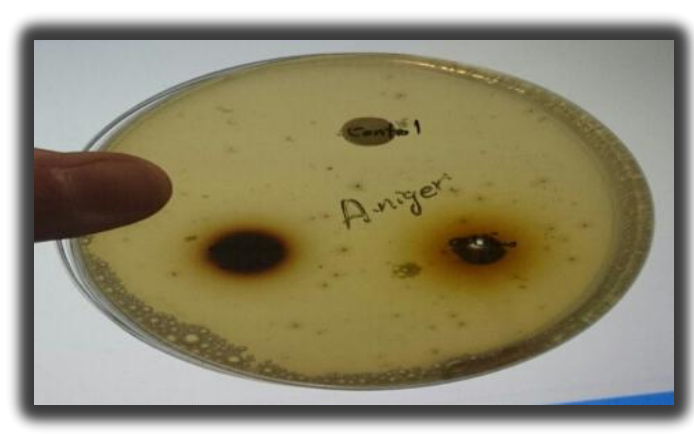

Figure(C)illustrated A.niger

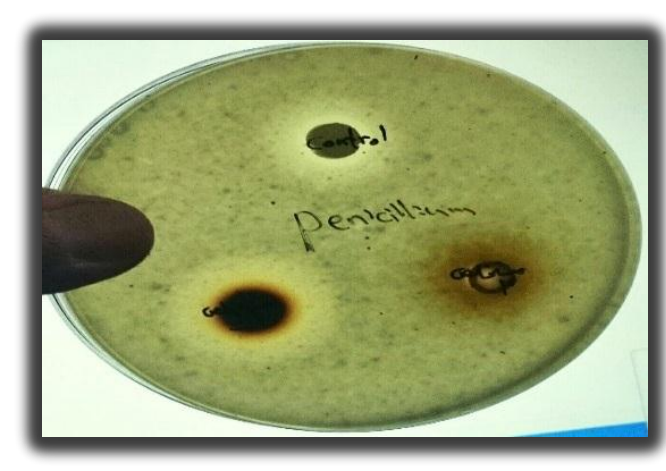

Figuer(B) illustrated Pencillium

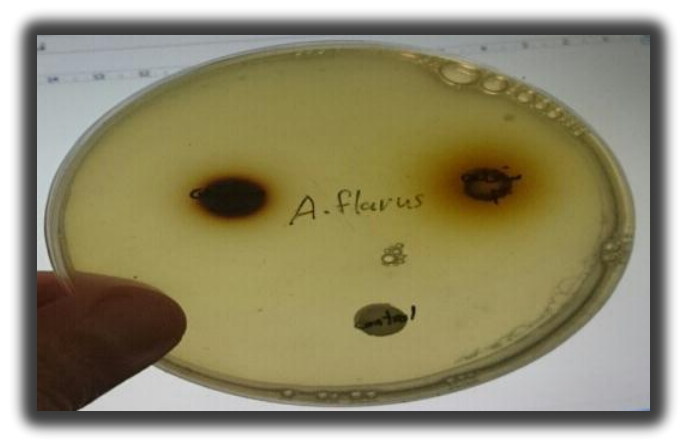

Figure(D)illustrated A.flavus

Fig(2) Effect of the Palm pollen extract on the fungal isolations.
A: Cladosporium
B: Pencillium
C: A.niger
D: A.flavus 


\section{0 -Discusion}

The antimicrobical activity of Palm pollen draws from containing the auxiliary anabolic materials as sterols, flavonoids ,alkaloids and saponoids, coumarin and pectin [9] , and the activity of the alcoholic extract may draw from the capacity of some material melting in alcohol more than in water.

[19] appeared that the activity of the Palm pollen extract against the bacterial species draw from its containing the flavonoids like querectin, and [20] indicated that the Palm pollen extract has an activity in inhibiting certain strains of bacteria including E.coli and staphylococcus as well as the fungus Fusarium oxysporium that is one of the morbigenous fungus to plant and isolated from soil and that because the pollen is rich with Cinnamic , flavonoid and Gallic acid, whreas [21] showed there was no important role for the aqueos extract of the Palm pollen against the numerous practical bacterial species.

[11] found that the crud ethanol extract had an important role in inhibiting numerous negative and positive gram bacterial species as Pseudomonas aeroginosa, Escherichia coli, Bacillus subtillis, streptococcus pyogenes, Staphylococcus aureus and Shiglla flexeneri.[22] found astrong impact of the palm pollen extract when $h$ compared between two kinds of dates :Dpp Tunisia and Dpp kerkenna against 10 species of bacteria and genera of fungi.The greatest inhibition was by using DPPK and ethylacetate against Klebsiella pneumonia with ratio ranged between $14 \pm 2.0 \mathrm{ml}$, and staphylococcus aureus with ratio $20 \pm 1.0 \mathrm{ml}$.The Fusarium oxysporium is sensitive by the extract with ratio $42 \pm 20 \mathrm{ml}$ and $29 \pm 1.0 \mathrm{ml}$ by using ethylacetate for both species DPPT and DPPK whears DPPT is hyer sensitive by using the acetone extract with an inhibitor ratio against Stapphylococcous aureus and Klebsilla .pneumonia attained $10 \pm 1.0$ and $5.5 \pm 0.5 \mathrm{ml}$,respectively whereas both species had no effect on the other fungi genera: Fusarium spp, R.sdani, P. catenulatum, Pencillum, F.phllophitum, A.niger.

These results agree with astudy done in Egypt when six compounds were isolated from the Palm pollen :caffeic acid ,Gallica acid , Coumaric acid, Chlorogenic acid Catchinad and quercetin to know their biological activity against six speciesof bacteria :E.coli, Klebsilla, Staphylococcus epedermids, Bacillius cereus and Micrococcus lutus. The greatest impact against staphylococcus with ratio attained $22 \mathrm{ml}$, and against fungi Candida albicans and A.niger[23].

[24] found also that the palm pollen had an impact on Candida alpicans it has caused disformation and apartical decay of the cell wall leading to its breakdown and noticed infiltration of the cytoplasm materials and attend ,dying the cell.

The studies showed that the flavonoids had activities against Candida albicans and Candida krusei and their presence in the extract may be responsible for the anti-fungal effects [25].

The resistance of A.niger and A.flavus to the plant extract may return to excrete many auxiliary anaholic material or Aflatoxin.

\section{CONFLICT OF INTERESTS}

There are no conflicts of interest.

\section{1- References}

[1] Caligor, Teresa. Translated by Hanadi Mezboudi. Pediatrics, First Edition, Author's Publishing House, Riyadh. 2013.

[2] Al oogi, Sabah Nasser. Physiology. Third Edition, Dar Al Fikr for Printing and Publishing, Hashemite Kingdom of Jordan - Amman. 2014.

[3] Geo .F . Brooks, Janet .S . Butel\& Stephen A. Morse. Medical Microbiology $21^{\text {th }}$ ed.Middle East Edition. 1998.

[4] Beswick, A .J. ;B .Lauely ;A.P. Fraises; A .L .Pahor and N. Brown. Detection Alloiococcus otitis in Mixed bacteria population from middle ear effusion of patients with otitis media.The Lancet.354 (31):386-388. 1999.

[5] Ellis, D. H. Clinical Mycology. The Human opportunistic mycosis Pfizer, NewYork. 1994.

[6] Krens A J, Builey C J. Oral antidiabetic agent: Current role 2 diabetes mellitus Drugs; 65,385-411. 2005.

[7] Barh D and Mazumdar B C. Comparative nutritive values of Palm saps before and after partial fermentation effective use of wild date (Phoenix sylvestris Rox b) Sapin treatment of anemia Research Journal of medicine of Medical Sciences,; 3,173-176. 2008.

[8] Nehdi I ,Omri S, Khalil MI and Al Resayes .S.I. Characteristics and Chemical Composition of Date Palm Phoenix Eanariensis Seeds and Seed Oil .Industrial crops and products; 32360 - 365. 2010

[9] Hamid, Rafah Razouk. A study of date palm at the level of sex hormones and antioxidants in the blood of adult male rabbits. $\mathrm{PhD}$ thesis .2013

[10] Al-Samarai ,A,H; Al-Salihi,F.and Al-Samarai ,R.R. Phytochemical constituents and nutrient evaluation of date palm (Phenix dactylifera ,L) Pollen grains .Tikrit journal of pure science 21(1).ISSN.1813-1662 .2016. 
[11] Kothari V .In vitro Antibacterial Activity in Seed extracts of Phoenix sylvestris Rox b (Palm), and Trico Santhes dioica L. (Cucurbitaceae) 2011.Current TErends in Biotechnology and Pharmacy, -5(1) 993-997. 2011.

[12] Shakibaa,M,Karimink,A,Parsia,P.”Antimicrobial activity of different part of phoenix dactifera”.In I.J.Mol.Clin Microbio, 1,107-111. 2011

[13]Prescott,L.M.,Harly,J.P.andKlein,D.A.,.Microbiology.4 ${ }^{\text {th }}$ ed.,5Wm.C.browncommunication.Inc.U.S.A.pp.417470.1999 .

[14] Koneman ,E.W., Allen ,S.D., Janda,W,M., Screckenberger,P.C.and Winn,W.C.W. Color Atlas and textbook of diagnostic Microbiology. ${ }^{\text {th }}$ ed ., Lippincott-Raven Publishers, philadephia, U.S.A.pp.195-218, 429-436. 1997

[15] Collee, J.G.; Fraser, A.G.; Marmion, B.P. and Simmons, A. Practical Medical Microbiology.4 ${ }^{\text {th }}$ ed, Short Course: 245 - 258. 1996

[16] Ahmed, N. M. The Study of the Fungus associated with The Halox and Family Plants and the Effect of the Extracts of These Plants in some Fungi and their Antibiotic. Master of Science. University of Tikrit. 2010

[17] Olyrinola,P.F:A. A laboratory manual of pharmaceutical microbiology ,idu,Abuja,Nigeria 69-105. 1996.

[18] Abdul Shahid and Abdel Karim.D. "Ispergillus isolates and diagnoses the types of fungus Aspergillus of patients with ear infection and fungal sensitivity of some fungal antibiotics. Anbar Journal of Veterinary Sciences". Volume (3) Number (2). 2010

[19] Loizzo,M.R. Sfatt, G.A,Tundis Conforti ,F,Ando,S,Menichini,F. Antimicrobial activity and cytotoxic city of cirsium tenoreanum Fitoterapia 75,577-580. 2004.

[20] - Khider , M,Elbanna ; Mahmoud , A,Owayss ,A.A. Egyptian Honeybee Pollen as Antimicrobial Antioxidant agents and Dietary Food Supplements .Food.Sci.Biotechnol 22-(5) 1-9. 2013.

[21] Perveen K , Bokhari N , Soliman D. Antibacterial activity of Phoenix dactytifera L . Leaf and Pit extracts against selected gram negative and gram positive pathogenic bacteria .Journal of Medicinal Plants Research,2012;6(2):296-300. 2012.

[22] Daoud .A; Drira Malika, Sana Bakari, Najla Hfaiedh , Kais Mnafgui, Adel kadri, Neji Gharsallah. Assessment of Poly Phenol Composition antioxidant and antimicrobial Properties of Various extracts of Date Palm Pollen (DPP) from Two Tunisian Cultivaris. Arabian Journal of Chemistry. 2015.

[23] Abed El-Azim, Mohamed H.M., Amani, M D El Mesalamy Fathy A Yassin and Salam A Kalil. Identification Phenolic and Biological Activities of Methanotic Extract of Date Palm pollen(Phoenix dactylifera) Microbial \& Biotechemical Techology 7:1.2015

[24]Shraideh,Z.A.,Khaled,H.Abu E.Heen,H.,Sallal,A.K.J. U Hrastructural effects of date extracts on (Candida albicans). Mycopathologia 142,119-123. 1998.

[25] Orhan D,D;Ozeelik B, Ozgen S and Ergun F.Antibacterial and fungal and antiviral activities of some Flavonoids Microbiological Research,2009, 165(6). 2009.

تم في هذه الدراسة عزل عدد من الأنواع البكتيرية والفطرية المصاحبة لألتهاب الأذن الخارجية و المأخوذة من مستشفى سامر اء العام وتثمل

الأنواع البكتيرية ( Pseudomonas , Staphylococcus aureus , Escherichia coli, Streptococcus pneumonia, Klebsiella spp (aeruginosa doctitera

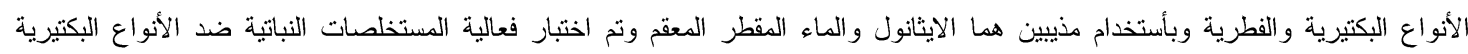

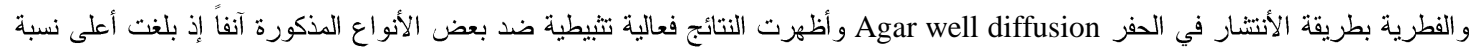

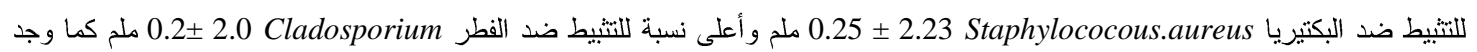
هقاومة لبكتيريا E.coli , Klebsiella وكلا الفطرين A.flavus , A.niger للمستخلص الكحولي كما ان المستخلص المائي لم يكن له أي تأثير ضد الأنو اع البكتيرية و الفطرية. الكلمات الدالة:Aspergillus flavus ، الرشانشيات، بنيسيليوم النيابة، المبغثرة. 